\title{
Opportunities for sustainable tourism development and nature conservation in Special Nature Reserve "Deliblatska peščara"
}

\author{
Igor Trišićc ${ }^{*}$ \\ ${ }^{1} \mathrm{PhD}$ student, University of Kragujevac, Faculty of Hotel Management and Tourism in \\ Vrnjačka Banja, Serbia
}

\begin{abstract}
The area of the Special Nature Reserve "Deliblatska peščara" has a huge capital of pristine nature. On the one hand, this is an important area for plant and animal species, while, on the other hand, it is attractive for tourists as important users of place. This area has sensitive ecosystems and is important for conservation of geodiversity. Precisely for this reason, it represents a significant tourist potential. The economic revenues of tourism can be used for proper monitoring and nature protection by directing the money to improve protection area system. It is one of the basic postulates of sustainable tourism development.
\end{abstract}

Keywords: tourism, management, sustainable tourism development, tourism and area protected

JEL classification: Z32, Q57

\section{Mogućnosti održivog turističkog razvoja i zaštite prirode u Specijalnom rezervatu prirode „Deliblatska peščara"}

Sažetak: Prostor Specijalnog rezervata prirode „Deliblatska peščara“ obuhvata ogroman kapital netaknute prirode. Ta sredina je značajna za biljni i životinjski svet sa jedne i privlačna za turiste kao korisnike prostora, sa druge strane. Poseduje osetljive ekosisteme i važna je za održavanje geodiverziteta. Upravo zbog toga, „Deliblatska peščara“ je značajan turistički potencijal. Pravilan monitoring i zaštita prirode, mogu iskoristiti ekonomske prihode od turističke potrošnje i usmeriti ih u unapređenje sistema zaštite prostora. To bi bio ujedno i jedan od osnovnih postulata održivog turističkog razvoja.

Ključne reči: turizam, upravljanje, održivi turistički razvoj, turizam i zaštićen prostor JEL klasifikacija: Z32, Q57

\section{Introduction}

The area of the Autonomous Province of Vojvodina has 135 protected natural sites on the surface of $141,044.65$ ha. This is $6.56 \%$ of the total surface of the territory of Vojvodina (Environment Protection Program of the Autonomous Province of Vojvodina for the Period 2016-2025 - "Official Gazette of AP Vojvodina", № 10/2016). The Special Nature Reserve 
(SNR) "Deliblatska peščara" constitutes a significant part in these natural resources. Within the protected area of this special nature reserve, there are diverse biocenoses inhabited by endemic plant and animal species, a fragile ecosystem, wetlands, significant parts of geodiversity, in which ecological goals are priorities in monitoring systems, protection, and preservation, and many other reasons for the preservation of this area as a unique spatial unit. For these reasons, the SNR "Deliblatska peščara" has a very significant tourism potential. Proper monitoring and protection can make use of the economic income from tourism consumption, and direct it towards the improvement of the area protection systems (Webb et al., 2018), which would be one of the basic postulates of sustainable tourism development. The role of the country is based on the adoption of certain legal regulations regarding the goals and models of the management of this area. In addition to the social-economic and catalyst function, tourism could have a great impact on the development and sustainability of Deliblato Sands. Properly planned tourism development can contribute to the economic, socio-cultural, and equally important environmental benefits of the destination. It is precisely the concept of sustainable tourism development that is based on this principle (Stojanović et al., 2014; Redžić, 2017).

This research paper focuses on models of sustainable tourism management in the protected area of the Deliblato Sands. The aim of this paper is the analytical research of written data, as well as the data obtained after the questionnaire had been conducted regarding the ways and the extent of the protected areas' impacts to tourism and travel decisions of potential users of this protected area. The research also includes data analysis concerning the importance of management and the establishment of protection levels and regimes.

\section{Background}

The Deliblato Sands is located in southern Banat and covers the area of about 35,000 ha (Decision on Adopting to Spatial Plan for Special-Purpose Area of Special Nature Reserve "Deliblatska peščara" ("Official Gazette of AP Vojvodina", № 8/2006)), of which 34,829 ha is the area of SNR "Deliblatska peščara" (Kovačev, 2014). The reserve occupies the territories (Figure 1) of the following local community areas: Alibunar, Vršac, Bela Crkva, Kovin, and Pančevo (Vesić, 2017). This large ellipsoidal-shape area is surrounded by agricultural surfaces. It ranges from $44^{\circ} 48^{\prime} N$ and $45^{\circ} 10^{\prime} N$, and $38^{\circ} 36^{\prime} E$ to $38^{\circ} 58^{\prime} E$ (Popović et al., 2012). In the area of the Deliblato Sands there is a semi-arid climate, with average precipitation of $633 \mathrm{~mm}$, and average air temperatures ranging from 9.5 to $11^{\circ} \mathrm{C}$. Extraordinary large fluctuations of air temperature have been recorded both during the year and during the day (Kovačev, 2014).

From the given data, it can be concluded that the SNR "Deliblatska peščara" has a favorable geographical location and climate which are also favorable to tourist activities.

The Sands were protected in 1965 primarily as a general nature reserve, and in February 2002, after rescission of this term, it was proclaimed as a I category SNR of national significance (Management Plan of the SNR "Deliblatska peščara", 2011; Kovačev, 2014). A special nature reserve is "an area with unchanged or slightly changed nature of remarkable significance for its uniqueness, rarity, or representability, which involves the habitat of endangered wild species of plants, animals, and fungi" (Delić et al., 2017). The area of the Deliblato Sands is rich in flora with more than 900 species, subspecies, and varieties of plants (Kovačev, 2014). Over 200 animal species with the status of natural rarities are present in this area (Amidžić, 2007; Mrkša, 2008). It is also a European natural rarity and the best-preserved sands in Europe. For its rich flora and fauna, it is one of the most internationally significant centers of biodiversity. Creating a protection plan should be one of the first steps in managing the protected areas for visitors, where it is important to ensure the 
best relationship between protected nature and visitors (Panjković, 2016). The Spatial Plan of the RS (2010-2020) ("Official Gazette of the RS" № 88/2010), provided the nomination for the enlistment of the Deliblato Sands in the List of Biosphere Reserves - UNESCO - MAB Program (Man and the Biosphere Programme) (Liburd \& Becken, 2017). Based on the IUCN categorization, the Deliblato Sands is under the IV category of protection (Kovačev, 2014). According to this nomenclature, this is the area of habitat or species management, and the area of the country managed by active protection measures in order to preserve the habitat and enable the environment for subsistence of certain species (IUCN-WCPA, 2018).

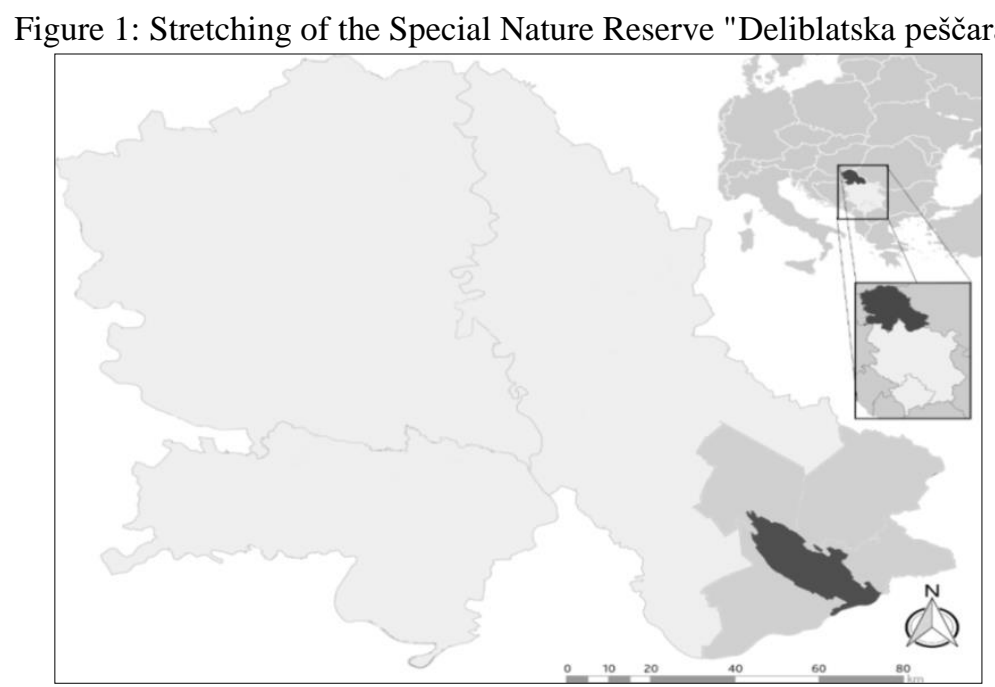

Source: Author

A three-degree protection regime has been established in this area: I degree of protection 2,354 ha; II degree of protection - 8,219 ha, and III degree of protection - 24,257 ha (Kovačev, 2014; Puzović et al., 2015).

The following activities are established in the three-degree system of protection:

The I Zone ( $6.76 \%$ of the territory) is designed exclusively for the preservation of authentic natural resources, with a restricted possibility of scientific research and education (Kovačev, 2014);

The II Zone (23.60\%) is designed for the preservation and improvement of existing natural resources, with the possibility of restricted use, including tourism. This is organized with ecological forms based on the preservation and improvement of nature (Lazić et al., 2008);

The III Zone (69.65\%) involves the largest area of this reserve. Any other forms of tourism without negative effects on the environment are allowed in this zone (Lazić et al., 2008; Kovačev, 2014).

It is important to include these restrictions and illegal activities when planning tourism development because their implementation supports the goals of sustainable tourism management and development (Maksin et al., 2018). Although sustainability is included in the developmental paradigm of the 1980s, it remains a priority. Sustainable development was defined as early as 1987 in the World Commission on Environment and Development (WCED) as "a development that meets the needs of the present, without compromising the ability of future generations to meet their needs" (Bosak, 2016). Ecological pillar of sustainable development is related to the protection of natural resources such as air, water, land, biodiversity, forests, mineral resources, and renewable energy sources (Pivašević \& 
Hafner, 2013). Therefore, the basic postulate of sustainable tourism development should be imperative in protecting the area of the SNR "Deliblatska peščara".

\section{Materials and methods}

At the beginning of 2018, the author conducted a study on traveling to the protected areas of Vojvodina and opinions about the significance of protection and sustainable tourism development within certain protected areas, including the area of the SNR "Deliblatska peščara". The survey was conducted among 210 potential travelers (109 females) who plan to visit this reserve again or for the first time. The structure of the respondents consisted of a total of 37 persons aged 17 to 25,121 persons aged 26 to 49, and 52 persons aged 50 or more. All respondents have traveled at least once. The cities inhabited by the respondents are Smederevo, Belgrade, Vršac, Bor, Kovin, Novi Sad, Pirot, Indjija, Niš, and Pančevo, which are significant tourist centers of Serbia. Within the written questionnaire, they were asked three questions regarding sustainable tourism development of the SNR "Deliblatska peščara". The respondents could circle one or more given answers to $2^{\text {nd }}$ and $3^{\text {rd }}$ question in this article.

The analysis of the respondents' answers can contribute to the constitution of the conclusions related to the planning of sustainable tourism development, and managing a protected natural area. Also, the results can refer to some future research regarding this special nature reserve.

\section{Results and discussion}

All the answers that may have be significant for constituting the conclusions related to the planning of sustainable tourism development and managing a protected natural area such as the SNR "Deliblatska peščara" are analyzed in this paper.

The first question in the questionnaire (Table 1) was: Do you consider that the inclusion of Special Nature Reserve "Deliblatska peščara" in tourism offer can contribute to an increase in the quality of a destination:

-agree;

-disagree.

Table 1: Do you consider that the inclusion of protected areas in tourist offer of Vojvodina can contribute to the increase in the quality of a destination?

\begin{tabular}{r|rl|r}
\hline & Structure & Agree & Disagree \\
\hline \multicolumn{1}{c|}{$\Sigma$} & & \\
$(17-25)$ & 37 respondents & $210=100 \%$ & 0 \\
$50>$ & 52 respondents & & \\
\hline
\end{tabular}

Source: Author

A total of $100 \%$ of the respondents voted for the inclusion of this protected area in a tourist offer, and are willing to visit such a destination. Analyzing the collected data, it is noted that all three age groups consider that the activation of protected areas can contribute to the quality of a destination. This result can be used when creating a travel program for this area, which is important for the realization of this travel motive. Natural potentials make the area of SNR "Deliblatska peščara" a significant spatial unit comprised of dune relief, a specific climate, and diverse flora and fauna. Therefore, this area is exceptionally attractive to visitors of various interests. Considering the significant economic and other functions of tourism, as well as individual values, the spatial plan of the Republic of Serbia and its economic policy give the opportunity and significance for the development of tourist activities in this reserve. 86 
In addition, the Tourism Development Strategy of Serbia establishes a selective approach, where rural and sustainable tourism are treated as priorities within many tourism activities (Forcan et al., 2016). Protected areas can contribute to the quality of a destination with international protection regimes. In terms of established international protection regimes and statuses, in SNR "Deliblatska peščara” we should name the following (Puzović et al., 2015):

- IBA (Important Bird Areas) significant for birds, with the of 48,758 ha;

- IBA Area "Labudovo Okno" - 6,488 ha;

- IPA (Important Plant Areas) significant for plants, with the of 35,332 ha;

- PBA (Prime Butterfly Areas) significant for butterflies, with the of 35,496 ha;

- Ramsar site "Labudovo Okno", protected since 2007, with the of 3,733 ha;

- ICPDR area along the Danube (International Commission for the Protection of the Danube River);

- DNPA (Dartmoor National Park Authority) area;

- EMERALD area - 34,829 ha;

- a potential NATURA 2000 area

The second question (Table 2) within the same questionnaire was: The choice of your future travel destination will include:

-visiting only cultural sites;

-visiting the Special Nature Reserve "Deliblatska peščara";

-visiting combined localities.

Table 2: The choice of your future travel destination will include?

\begin{tabular}{|r|c|ccc|}
\hline \multicolumn{2}{|c|}{ Structure } & $\begin{array}{c}\text { Visiting Only } \\
\text { Cultural Sites }\end{array}$ & $\begin{array}{c}\text { Visiting the } \\
\text { SNR }\end{array}$ & $\begin{array}{c}\text { Visiting } \\
\text { Combined } \\
\text { Localities }\end{array}$ \\
\hline \multicolumn{2}{|c|}{$\boldsymbol{\Sigma}$} & $30=14,29 \%$ & $70=80,95 \%$ & $10=4,76 \%$ \\
\hline$(17-25)$ & 37 respondents & 6 & 26 & 5 \\
$(26-49)$ & 121 respondents & 20 & 96 & 5 \\
$50>$ & 52 respondents & 4 & 48 & $/$ \\
\hline
\end{tabular}

Source: Author

By analyzing the data in Table 2, we can see that the vast majority of the respondents $(80.95 \%)$ chose the answer form which their future trip would include a visit to this protected area. A total of $14.29 \%$ of the respondents will visit only cultural sites, while $4.76 \%$ of the respondents will visit combined localities. The highest number of respondents aged 26-49 (96 respondents) opted for the inclusion of this special nature reserve in the tourist offer. The conclusion that the protected natural localities will be a part of future travel in a vast majority of the respondents is based on the great significance of these areas to tourism, when selecting destinations, in almost all ages of tourists.

The third question (Table 3) within the same questionnaire was: How would you support the sustainability and protection of the Special Nature Reserve "Deliblatska peščara":

-by promotion;

-by ecological activity;

-by educating others on conscientious ecological behavior. 
Table 3: How would you support the sustainability and protection of this Protected Area?

\begin{tabular}{|r|r|r|r|r|}
\hline \multicolumn{2}{|c|}{ Structure } & $\begin{array}{c}\text { by } \\
\text { Promotion }\end{array}$ & $\begin{array}{c}\text { by Ecological } \\
\text { Activities }\end{array}$ & $\begin{array}{c}\text { by Educating } \\
\text { Others }\end{array}$ \\
\hline \multicolumn{2}{|c|}{$\boldsymbol{\Sigma}$} & $19=9,04 \%$ & $196=93,33 \%$ & $205=97,63 \%$ \\
\hline$(17-25)$ & 37 respondents & 15 & 27 & 32 \\
$(26-49)$ & 121 respondents & 4 & 117 & 121 \\
$50>$ & 52 respondents & $/$ & 52 & 52 \\
\hline
\end{tabular}

Source: Author

The data analysis in Table 3 shows that $196-93.33 \%$ and $205-97.63 \%$ of the respondents chose the answers under 2 and 3, which means that they would support the sustainability and protection by conscientious behavior and educating others in this protected area. A total of $9.04 \%$ of the respondents opted for the promotion as a means of support to sustainable development (15 respondents aged 17-25 and 4 respondents aged 26-49). The obtained results indicate the importance of having a sustainable conscience in the vast majority of the respondents. In addition to their own positive opinions about sustainable development, the respondents are willing to educate the existing or potential visitors of this protected area about the behavior and habits in this protected area. Implementation of sustainable development also involves understanding the significance of species existence, recognizing the degree of their vulnerability and preventing their extinction by adopting various measures and activities (Kostić \& Petrović, 2013; Bennett et al., 2018). The planning of protection also includes the development of efficient implementations which are based on the task and goals of the protected area manager, interests and needs of visitors, as well as the presentation of unique and significant spatial characteristics (Smrekar et al., 2016). The ideas of sustainable development have always affected tourism. They have arisen as a reaction to the global effects of human activities and negative outcomes of great developmental projects on the environment (Štetić \& Trišić, 2018).

The obtained results of the questionnaire are a good sample and significant basis when planning sustainable tourism development in the protected natural area of the SNR "Deliblatska peščara". The motive and conscience about the significance of such tourist destinations, which is present in the vast majority of the respondents, represents a significant potential for the development of tourism, and the obtained results of the survey show that the SNR has the required attractions for the development of the specific forms of tourism, such as ecotourism, adventure tourism, rural tourism, health tourism, sports, hunting, fishing, i.e. the forms of tourism based on natural resources (Trišić, 2018a). The natural potential of this reserve, the proximity of urban settlements such as Belgrade, Pančevo, Bela Crkva, and Vršac, the proximity of the Danube and Romanian border can be used for development of diverse forms of tourism. First of all, nautical tourism would be significant and it would be developed on the Danube, but also on Nera River and Karaš River, which have recreational potentials. It is necessary to strengthen the hunting and fishing tourism in the Deliblato Sands hunting area, but also in surrounding hunting areas. Then, transit tourism is also significant and it should be more developed after the implementation of the construction plan of Corridor $11^{\text {th }}$ from Vršac, through Belgrade to Montenegro. Ecotourism, rural tourism, excursion tourism, and manifestation tourism would be the primary forms of tourist movements in the area of the SNR "Deliblatska peščara" (Štetić et al., 2014). Ecotourism, with ecological and sustainable components, would be the most significant for the protection of this area (Trišić et al., 2018). Ecotourism and rural tourism could certainly not be developed without preserved nature and cooperation with the local community (Trišić, $\underline{2018 \mathrm{~b}}$ ). Therefore, for ecotourism and rural tourism users, the destinations with protected areas are of particular importance (Cochrane, 2017). In such an area, tourism is both useful 
and harmful, while its effects are interacting in various ways (Njegovan et al., 2015). Ecotourism would here represent a model of aspiration of possible negative consequences, which would manifest themselves in certain ways. This means that ecotourism can condition a number of positive effects in the environment, where tourists satisfy their needs. Awareness about the significance of the preservation of space and the improvement of the environment can be developed through tourism. Ecotourism improves quality and positively affects the environment (Eagles-Paul, 2014).

Through ecotourism, the following can be achieved:

- $\quad$ raising the awareness about the significance of the environment (Kostić \& Petrović, 2015);

- protecting nature, natural functions, and space in the function of tourism;

- improving the total aesthetic quality of the environment (Čučulović et al., 2012).

Tourism can provide a positive economic contribution to all users of a protected area. For instance, carefully regulated and organized tourism, as is the case with small groups interested in science education, could help fund research and protection. Such income has already directly helped the establishment of national park financing, especially in developing countries (Newsone et al., 2013). Tourism is seen as a mechanism for replacing lost finances through different methods, including donations, tickets, rental fees and licenses, the taxation of tourist retailers, and economic subjects related to tourism (Holden, 2013). Successful implementation of ecological components, environmental and tourism protection, and giving priority to those products organized according to ecological standards are imperatives in future conducting of tourism marketing activities in this protected area (Vujović et al., 2012). Ecotourism is one of the most widely accepted forms of space use because it has positive results on the level of total sustainable development (Buckley, 2013). Only recently has ecotourism become one of the routes and safe models of tourism development of Deliblato Sands through the opening and promotion of facilities and educational trails. The tourism offer of this protected area includes the aforementioned educational and recreational health trails, which additionally enriches the visits to the reserve (Pantelić et al., 2012; Kovačev, 2014).

Analyzing the mentioned values and results, tourism management in the area of SNR should be based on the 6 basic principles of sustainable development and nature protection:

- $\quad$ using the space for tourism purposes with minimal impacts on the environment and the local community (Fennell, 2015a);

- raising awareness of the sustainability of natural and cultural systems of area development, as well as involving the local community and visitors in resolving issues affecting those systems (Holden, 2016);

- emphasizing the significance of the preservation and management of a protected area (Corral-Verdugo \& Frias-Armenta, 2016);

- timely and long-term participation of the local community in decision-making processes, that determine the form and size of tourism that should be implemented (Weaver \& Lawton, 2014);

- to direct economic benefits to the local community. They should complement other income achieved through regular jobs (agriculture, hunting, and fishing, etc.) (Bushell \& Bricker, 2017);

- providing opportunities for the local community to participate in the limited use of the resources from protected areas (Fennell, 2015b). 


\section{Conclusion}

By analyzing the given data in the paper, it can be concluded that the SNR "Deliblatska peščara" is a significant treasure of rare natural forms and representatives of flora and fauna. The majority of them is endangered, both by natural and anthropogenic factors. On the other hand, a favorable position, the relief, climate, and biogeography enable the use of these areas in recreational purposes. Every use represents additional stress for the area. Under the pressure of users, the elements of the area are modified because they are very often adapted to the needs of users. From all of the above, it is necessary to implement the protection regime and to control, minimize, or completely eliminate certain activities. It certainly should not imply a ban on using it for tourism purposes. The key to successful improvement of the values of the space and tourist potentials is specifically sustainable tourism development. It involves intensifying of economic, ecological, and socio-cultural benefits (Valdivieso et al., 2015). Besides the users' satisfaction and the preservation of natural values, the local community also must have certain benefits from the protection and improvement of tourism. Only such a sustainable environment can be a significant tourism destination (Buclet \& Lazarević, 2015). Protected natural areas are very important when selecting a trip, which can be concluded by analyzing the results of the conducted survey which is presented in this paper. Tourists who are very aware of the protection and improvement of such natural resources are opting for visiting protected natural resources in large numbers, and want to share their knowledge with the existing or potential travelers. The results of the survey indicate the significance of the existence of such destinations, which can result in economic benefits. After engaging the members of the local community in tourism planning and managing of the protected area, the basic demand for sustainable tourism development would be achieved. The concluding observations indicate that the SNR "Deliblatska peščara" can be an area of active sustainable development and nature protected. The role of the state and the legislation regulating the model, the system of protection and financing will be provided by the results of future research.

\section{References}

1. Amidžić, L., Krasulja, S., \& Belij, S. (Eds.) (2007). Zaštićena prirodna dobra Srbije [Protected Natural Resources in Serbia]. Beograd: Ministarstvo zaštite životne sredine, Zavod za zaštitu prirode Srbije.

2. Bennett, N. J., Whitty, T. S., Finkbeiner, E., Pittman, J., Bassett, H., Gelcich, S., \& Allison, E. H. (2018). Environmental Stewardship: A Conceptual Review and Analytical Framework. Environmental Management, 61(4), 597-614. https://doi.org/10.1007/s00267-017-0993-2

3. Bosak, K. (2016). Tourism, Development and Sustainability. In: S. F. McCool, \& K. Bosak (Eds.), Reframing Sustainable Tourism (pp. 33-44). New York: Springer. https://doi.org/10.1007/978-94-017-7209-9

4. Brankov, J. (2010). Ekološki turizam u zaštićenim objektima prirode u Banatu, knjiga 81 [Ecological Tourism in Protected Natural Assets in Banat, Special Issues № 81]. Beograd: Geografski institut „Jovan Cvijić“, Srpska akademija nauka i umetnosti.

5. Buckley, R. (2013). Defining Ecotourism: Consensus on Core, Disagreement on Detail. In: R. Ballantyne, \& J. Packer (Eds.), International Handbook on Ecotourism (pp. 9-14). Cheltenham: Edward Elgar.

6. Buclet, N., \& Lazarević, D. (2015). Principles for Sustainability: the Need to Shift to A Sustainable Conventional Regime. Environment, Development and Sustainability, 17(1), 83-100. https://doi.org/10.1007/s10668-014-9539-4 
7. Bushell, R., \& Bricker, K. (2017). Tourism in Protected Areas: Developing Meaningful Standards. Tourism and Hospitality Research, 17(1), 106-120. http://doi.org/10.1177/1467358416636173

8. Cochrane, J. (2017). Tourism Resilience in UK National Parks. In: R. W. Butler (Ed.), Tourism and Resilience (pp. 121-136). Wallingford, Oxfordshire: CABI.

9. Coral-Verdugo, V., \& Frias-Armenta, M. (2016). The Sustainability of Positive Environments. Environment, Development and Sustainability, 18(4), 965-984. https://doi.org/10.1007/s10668-015-9701-7

10. Čučulović, R., Mrkša, M., Đekić, T., \& Čučulović, A. (2012). Mogućnosti razvoja ekoturizma u Srednjem Banatu [Opportunities for Development of Ecotourism in Central Banat]. Glasnik Srpskog geografskog društva, 92(3), 109-130. https://doi.org/10.2298/GSGD1203109C

11. Delić, J., Cvijanović, D., \& Prentović, R. (2017). Uticaj lovnog turizma na zaštićena područja, monografija [The Impact of Hunting Tourism on Protected Areas, Monograph]. Vrnjačka Banja: Fakultet za hotelijerstvo i turizam, Univerzitet u Kragujevcu.

12. Eagles-Paul, F. J. (2014). Research Priorities in Park Tourism. Journal of Sustainable Tourism, 22(4), 528-549. https://doi.org/10.1080/09669582.2013.785554

13. Fennell, D. A. (2015a). Tourism and the Precautionary Principle in Theory and Practice. In: C. M. Hall, S. Gössling, \& D. Scott (Eds.), The Routledge Handbook of Tourism and Sustainability (pp. 67-77). London \& New York: Routledge, Taylor \& Francis Group.

14. Fennell, D. A. (2015b). Ecotourism. London \& New York: Routledge.

15. Forcan, D., Ivić, M., Đuranović, D., \& Vuković, V. (2016). Sustainable Development of Rural Areas - Case Studies Vojvodina - Serbia. School of Business, 2, 1-13. https://doi.org/10.5937/skolbiz2-11666

16. Holden, A. (2013). Protected Areas and Tourism. In: A. Holden, \& D. Fennell (Eds.), The Routledge Handbook of Tourism and the Environment (pp. 276-284). London \& New York: Routledge, Taylor \& Francis Group.

17. Holden, A. (2016). Environment and Tourism. $3^{\text {th }}$ edition. London \& New York: Routledge, Taylor \& Francis Group.

18. IUCN-WCPA, (2018). Parks, The International Journal of Protected Areas and Conservation, volume 24.1, Gland, Switzerland: IUCN. https://doi.org/10.2305/IUCN.CH.2018.PARKS-24-1.en

19. Kadović R., Spasov P., Ali Bohajar Y. M., Belanović Simić S., \& Košanin O. (2014). Analysis of Aridity Indicators in the Deliblato Sands. Bulletin of the Faculty of Forestry, 109, 97-112. https://doi.org/10.2298/GSF1409097K

20. Kostić, M., \& Petrović, M. (2013). Uloga očuvanja biodiverziteta kao faktor razvoja ekoturizma planine Goč [The Importance of Biodiversity Conservation as a Factor of Ecotourism Development at Goč Mountain]. Menadžment u hotelijerstvu i turizmu Hotel and Tourism Management, 1(1), 56-66.

21. Kostić, M., \& Petrović, M. (2015). Značaj očuvanja biodiverziteta u kulturnoj evoluciji čoveka kao ključni faktor održivog razvoja [The Importance of Biodiversity Conservation in Human Cultural Evolution as a Key Factor for Sustainable Development]. Menadžment u hotelijerstvu i turizmu - Hotel and Tourism Management, 3(1), 68-76.

22. Kovačev, N., Romelić, J., Pivac, T., \& Lukić, T. (2014). Izleti kao primarni i prateći oblici drugih turističkih kretanja u Deliblatskoj peščari [Trips as Primary and Associated Forms of Other Tourist Deliblato Sands Movement]. Zbornik radova, 43-2, (pp. 137 155). Novi Sad: Univerzitet u Novom Sadu, Prirodno-matematički fakultet, Departman za geografiju, turizam i hotelijerstvo.

23. Lazić, L., Pavić, D., Stojanović, V., Tomić, P., Romelić, J., Pivac, T., ... Kicošev, S. (2008). Zaštićena prirodna dobra i ekoturizam Vojvodine [Protected Natural Resources 
and Ecotourism in Vojvodina]. Novi Sad: Univerzitet u Novom Sadu, Prirodnomatematički fakultet, Departman za geografiju, turizam i hotelijerstvo.

24. Liburd, J. J., \& Becken, S. (2017). Values in Nature Conservation, Tourism and UNESCO World Heritage Site Stewardship. Journal of Sustainable Tourism, 25(12), 1719-1735. https://doi.org/10.1080/09669582.2017.1293067

25. Lukić, T., Leščešen, I., Sakulski, D., Basarin, B., \& Jordaan, A. (2016). Rainfall Erosivity as an Indicator of Sliding Occurrence Along the Southern Slopes of the Bačka Loess Plateau: A Case Study of the Kula Settlement, Vojvodina (North Serbia). Carpathian Journal of Earth and Environmental Sciences, 11(2), 303-318.

26. Maksin, M., Ristić, V., Nenković-Riznić, M., \& Mićić, S. (2018). The Role of Zoning in the Strategic Planning of Protected Areas: Lessons Learnt From EU Countries and $\begin{array}{llll}\text { Serbia. } \quad \text { European Planning } & \text { Studies, }\end{array}$ https://doi.org/10.1080/09654313.2018.1426736

27. Mrkša, M. (2008). Turistička valorizacija specijalnih rezervata prirode Vojvodine, naučna monografija [Tourism Valorization of Special Nature Reserves in Vojvodina, Scientific Monographs]. Beograd: Srpsko geografsko društvo.

28. Newsone, D., Moore, S. A., \& Dowling, R. K. (2013). Natural Area Tourism, Ecology, Impacts and Management. $2^{\text {nd }}$ edition. Bristol: Channel View Publications.

29. Njegovan, Z., Demirović, D., \& Radović, G. (2015). Upravljanje održivim razvojem ruralnog turizma u Vojvodini [Managing Sustainable Development of Rural Tourism in Vojvodina], Škola biznisa, 1, 68-79. https://doi.org/10.5937/skolbiz1-7899

30. Odluka o donošenju prostornog plana područja posebne namene specijalnog rezervata prirode „Deliblatska peščara“, („Sl. list AP Vojvodine", br. 8/2006) [Decree on Proclamation of Purpose Area Spatial Plan of Special Nature Reserve "Deliblatska peščara" (“Official Gazette of AP Vojvodina”, № 8/2006)].

31. Panjković, B. (2016). Zaštićena područja prirode u AP Vojvodini, status zaštite $i$ finansiranje u kontekstu evropskih integracija [Protected Areas in Vojvodina, Status and Funding in the Context of European Integration]. Vršac: Ekološki centar „Stanište“.

32. Pantelić, M., Stamenković, I., \& Purić-Samardžija, J. (2012). Razvoj ekoturizma na prostoru specijalnog rezervata prirode „Deliblatska peščara“ [Development of Ecotourism and the Importance of the Preservation of the Autochthon Biotope in Pannonian Plain on the Area of the Special Nature Reserve "Deliblato Sands"]. Zbornik radova, 41, (pp. 235-247). Novi Sad: Univerzitet u Novom Sadu, Prirodno-matematički fakultet, Departman za geografiju, turizam i hotelijerstvo.

33. Pivašević, J., \& Hafner, P. (2013). Institucionalna dimenzija održivog razvoja [Institutional Dimension of Sustainable Development]. Škola biznisa, 3-4, 119-128. https://doi.org/10.5937/skolbiz1304119P

34. Plan upravljanja SRP „Deliblatska peščara“ [Management Plan of the Special Nature Reserve "Deliblatska peščara”], (2011). Petrovaradin: JP „Vojvodinašume“.

35. Popović, Z., Smiljanić, M., Matić, R., Kostić, M., Nikić, P., \& Bojović, S. (2012). Phytotherapeutical Plants From the Deliblato Sands (Serbia): Traditional Pharmacopoeia and Implications for Conservation. Indian Journal of Traditional Knowledge, 11(3), 385-400.

36. Program zaštite životne sredine Autonomne Pokrajine Vojvodine za period 2016-2025. godine (,Sl. list AP Vojvodine", br. 10/2016) [Environment Protection Programme of AP Vojvodina, for the Period 2016-2025 (“Official Gazette of AP Vojvodina”, № 10/2016)].

37. Prostorni plan RS (2010-2020), („Sl. glasnik RS“ br. 88/2010) [Spatial Plan for The Republic of Serbia (2010-2020), (“Offical Gazette of RS”, № 88/2010)].

38. Puzović, S., Panjković, B., Tucakov, M., Stojnić, N., Sabadoš, K., Stojanović, T., ... Stanišić, J. (2015). Upravljanje prirodnom baštinom u Vojvodini [Natural Heritage 
Management in Vojvodina]. Novi Sad: Republika Srbija, Autonomna Pokrajina Vojvodina, Pokrajinski sekretarijat za urbanizam, graditeljstvo i zaštitu životne sredine, Pokrajinski zavod za zaštitu prirode.

39. Redžić, D. (2017). Uloga ekoturizma u održivom razvoju turizma [The Role of Ecotourism in Sustainable Tourism Development]. Menadžment u hotelijerstvu i turizmu - Hotel and Tourism Management, 5(2), 106-115.

40. Smrekar, A., Šmid Hribar, M., Tiran, J., \& Erhartič, B. (2016). A Methodological Basis for Landscape Interpretation: The Case of the Ljubljana Marsh. Acta Geographica Slovenica, 56(2), 279-290. https://doi.org/10.3986/AGS.875

41. Štetić, S., \& Trišić, I. (2018). The Role and Importance of Ecosystems in Creating Tourism Activities. Menadžment $u$ hotelijerstvu $i$ turizmu - Hotel and Tourism Management, 6(2), 35-46. https://doi.org/10.5937/menhottur1802043S

42. Štetić, S., Cvijanović, D., \& Šimičević, D. (2014). Posebni oblici turizma Dunavskog regiona Srbije, monografija [Specific Forms of Tourism in the Danube Region of Serbia, Monograph]. Beograd: Institut za ekonomiku poljoprivrede.

43. Stojanović, V., Đorđević, J., Lazić, L., Stamenković, I., \& Dragićević, V. (2014). The Principles of Sustainable Development of Tourism in the Special Nature Reserve "Gornje Podunavlje" and Their Impact on the Local Communities. Acta Geographica Slovenica, 54(2), 391-400. https://doi.org/10.3986/AGS54407

44. Trišić, I. (2018a). Sustainable Tourism Management of Special Nature Reserve "Deliblatska Peščara“. In: J., Damnjanović, N. Pavlović, \& B. Stankov (Eds.), Book of Abstracts, International Scientific and Expert Conference, Economic Development and Competitiveness of European Countries: Achievements - Challenges - Opportunities (pp. 160-163). Novi Sad: School of Business.

45. Trišić, I. (2018b). Ciljevi održivog turističkog razvoja i upravljanja u Nacionalnom parku „Fruška gora“" [The Goals of the Sustainable Tourism Development and Management in the Fruška Gora National Park]. Turističko poslovanje, 22, 5-17. https://doi.org/10.5937/TurPos1822005T

46. Trišić, I., \& Kostić, M. (2018). Značaj zaštićenih prirodnih područja za razvoj turističke destinacije [The Importance of Protected Natural Areas for the Development of Tourism Destination]. Book of Proceedings, Hotelplan 2018, $7^{\text {th }}$ International Congress (pp. 414 424), Belgrade: The College of Hotel Management.

47. Trišić, I., Štetić, S., \& Krstić, V. (2018). Possibilities to prevent negative environmental impacts. Economic of Agriculture, 65(4), 1599-1614. https://doi.org/10.5937/ekoPolj1804599T

48. Valdivieso, J. C., Eagles-Paul, F. J., \& Gil, J. C. (2015). Efficient Management Capacity Evaluation of Tourism in Protected Areas. Journal of Environmental Planning \& Management, 58(9), 1544-1561. https://doi.org/10.1080/09640568.2014.937479

49. Vesić, M. (2017). Weekend Tourism and Unplanned Construction in Deliblato Sands. Collection of Papers - Faculty of Geography at the University of Belgrade, 65(1a), 419432.

50. Vujović, S., Cvijanović, D., \& Štetić, S. (2012). Destinacijski koncept razvoja turizma [Destination Concept of Tourism Development]. Beograd: Institut za ekonomiku poljoprivrede.

51. Weaver, D., \& Lawton, L. (2014). Tourism Management. $5^{\text {th }}$ edition. Milton: John Wiley \& Sons.

52. Webb, J. A., Watts, R. J., Allan, C., \& Conallin, J. C. (2018). Adaptive Management of Environmental Flows. Environmental Management, 61(3), 339-346. https://doi.org/10.1007/s00267-017-0981-6 